\title{
Angiotensin II Type 1 Receptor-Dependent Oxidative Stress Mediates Endothelial Dysfunction in Type 2 Diabetic Mice
}

\author{
Wing Tak Wong, ${ }^{1,2, \star}$ Xiao Yu Tian, ${ }^{1,2, *}$ Aimin $X u^{3}$ Chi Fai Ng, ${ }^{4}$ Hung Kay Lee, ${ }^{5}$ Zhen Yu Chen, \\ Chak Leung $\mathrm{Au}^{1,2}$ Xiaoqiang Yao, ${ }^{1,2}$ and Yu Huang ${ }^{1,2}$
}

\begin{abstract}
The mechanisms underlying the effect of the renin-angiotensin-aldosterone system (RAAS) inhibition on endothelial dysfunction in type 2 diabetes are incompletely understood. This study explored a causal relationship between RAAS activation and oxidative stress involved in diabetes-associated endothelial dysfunction. Daily oral administration of valsartan or enalapril at $10 \mathrm{mg} / \mathrm{kg} /$ day to $d b / d b$ mice for 6 weeks reversed the blunted acetylcholine-induced endothelium-dependent dilatations, suppressed the upregulated expression of angiotensin II type 1 receptor $\left(\mathrm{AT}_{1} \mathrm{R}\right)$ and $\mathrm{NAD}(\mathrm{P}) \mathrm{H}$ oxidase subunits $\left(\mathrm{p} 22^{\text {phox }}\right.$ and $\left.\mathrm{p} 47^{\mathrm{phox}}\right)$, and reduced reactive oxygen species (ROS) production. Acute exposure to $\mathrm{AT}_{1} \mathrm{R}$ blocker losartan restored the impaired endotheliumdependent dilatations in aortas of $d b / d b$ mice and also in renal arteries of diabetic patients (fasting plasma glucose level $\geq 7.0 \mathrm{mmol} / \mathrm{l})$. Similar observations were also made with apocynin, diphenyliodonium, or tempol treatment in $d b / d b$ mouse aortas. DHE fluorescence revealed an overproduction of ROS in $d b / d b$ aortas which was sensitive to inhibition by losartan or ROS scavengers. Losartan also prevented the impairment of endothelium-dependent dilatations under hyperglycemic conditions that were accompanied by high ROS production. The present study has identified an initiative role of $\mathrm{AT}_{1} \mathrm{R}$ activation in mediating endothelial dysfunction of arteries from db/db mice and diabetic patients. Antioxid. Redox Signal. 13, 757-768.
\end{abstract}

\section{Introduction}

$\mathbf{T}$

YPE 2 DIABETES MELLITUS is associated with an increased risk of cardiovascular complications (27). Although the exact mechanisms are only partially understood, endothelial dysfunction plays a critical role in the initiation and progression of diabetic vascular diseases (15). The endothelium is essential for the maintenance and regulation of vascular homeostasis, by releasing both endothelium-derived relaxing factors such as nitric oxide (NO) and contracting factors such as reactive oxygen species (ROS). Endothelial dysfunction due to a reduced NO bioavailability is one of important early events in the development of hypertension, diabetes, and atherosclerosis $(8,41)$. The degree of reduced endothelium-derived NO predicts the severity of future vascular events (42).

Elevated ROS production, which is manifest in hypertension, diabetes, and atherosclerosis, is also one of the major initiators for endothelial dysfunction $(8,41)$ by direct inactivation of endothelium-derived NO. It is thus of great importance to define and explore oxidative mechanisms involved in endothelial dysfunction in type 2 diabetes (19). Sources of endogenous ROS that cause endothelial dysfunction include NAD(P)H oxidases (7) and endothelial nitric oxide synthase (eNOS) uncoupling (31).

The role of the renin-angiotensin-aldosterone system (RAAS) had been best defined in hypertension due to the wide application of RAAS blockers for lowering blood pressure. Of importance, existing evidence suggests a significant role of a local RAAS in the vascular wall as a key negative regulator of endothelial function in diabetes as well. Chronic angiotensin converting enzyme (ACE) inhibition improves endothelial function and cardiovascular outcomes in type 2 diabetic patients $(14,30,32,47)$. Apart from ACE inhibitors, angiotensin receptor blockers (ARBs) are also effective in improving cardiac function and reducing arterial stiffness in

\footnotetext{
${ }^{1}$ Institute of Vascular Medicine and Li Ka Shing Institute of Health Sciences, and ${ }^{2}$ School of Biomedical Sciences, Chinese University of Hong Kong, China.

${ }^{3}$ Department of Medicine and Pharmacology, University of Hong Kong, Hong Kong, China.

Departments of ${ }^{4}$ Surgery, ${ }^{5}$ Chemistry, and ${ }^{6}$ Biochemistry, Chinese University of Hong Kong, China.

*These authors contributed equally to this work.
} 
diabetic patients $(4,11,16,35,44)$. Local and circulating angiotensin II (Ang II) is an important mediator of both metabolic and vascular dysfunction in diabetes (6). Animal studies also provided evidences for RAAS blockers in diabetes. ARB improve vascular function in type I diabetic rat $(2,36)$. ARB may ameliorate diabetic vasculopathy and nephropathy through prevention of eNOS uncoupling $(31,34,45)$. Ang II binds to both Ang II type $1\left(\mathrm{AT}_{1} \mathrm{R}\right)$ and type 2 receptor $\left(\mathrm{AT}_{2} \mathrm{R}\right)$ (43). Most known detrimental effects of Ang II in vasculature are attributed to $\mathrm{AT}_{1} \mathrm{R}$ which is linked to $\mathrm{NAD}(\mathrm{P}) \mathrm{H}$ oxidase activation and ROS production (21). Hyperglycemia also upregulates the $\mathrm{AT}_{1} \mathrm{R}$ in vascular smooth muscle cells (37). However, the functional implications and the precise intracellular mechanisms by which $\mathrm{AT}_{1} \mathrm{R}$ activation and subsequent oxidative stress in diabetes that in turn impairs vasodilatation are not thoroughly understood.

In the present study, we examine the hypotheses that the upregulation of $\mathrm{AT}_{1} \mathrm{R}$ together with oxidative stress plays a critical role in the induction and maintenance of endothelial dysfunction in aortas of type 2 diabetic $d b / d b$ mice and in renal arteries from type 2 diabetic patients.

\section{Materials and Methods}

\section{Animal model}

All animal experiments were performed on type 2 diabetic mice (C57BL/KSJ) lacking the gene encoding for leptin receptor $(d b / d b)$ and heterozygote $\left(d b / m^{+}\right)$control which were supplied by Chinese University of Hong Kong (CUHK) Laboratory Animal Service Center after an approval was obtained from the Animal Experimentation Ethics Committee, CUHK. Mice were kept in a temperature-controlled holding room $\left(22^{\circ}-24^{\circ} \mathrm{C}\right)$ with a 12 -h light/dark cycle, and fed a standard diet and water ad libitum. At the age of 12 weeks, adult male $d b / d b$ mice were treated for 6 weeks with valsartan or enalapril at $10 \mathrm{mg} / \mathrm{kg}$ body weight/day or vehicle via oral gavage. Plasma glucose levels were determined using a blood glucose meter (Ascenia ELITE ${ }^{\circledR}$ XL, Bayer, IN). Systolic blood pressure was measured by a tail-cuff method.

\section{Human renal arteries}

Human renal arteries were obtained during surgery after informed consent from kidney cancer patients, aged between 56 and 82 years old, undergoing nephrectomy. One artery was obtained from each patient. The group of diabetic patients had a fasting plasma glucose level $\geq 7.0 \mathrm{mmol} / 1(126 \mathrm{mg} / \mathrm{dl})$ or $2-\mathrm{h}$ plasma glucose $\geq 11.1 \mathrm{mmol} / \mathrm{L}(200 \mathrm{mg} / \mathrm{dl})$.

\section{Plasma lipid profile and insulin in mice}

Plasma levels of total cholesterol and triglyceride were determined using enzymatic methods (Stanbio, Boerne, TX) and plasma insulin level was assayed by enzyme immunoassay (Mercodia, Uppsala, Sweden).

\section{Isometric force measurement}

After mice were sacrificed by $\mathrm{CO}_{2}$ inhalation, the thoracic aortas were rapidly removed and placed in oxygenated icecold Krebs-Henseleit solution. Changes in isometric tension of vessels were recorded in a Multi Myograph System (Danish Myo Technology, Aarhus, Denmark) as previously described
(24), and changes in isometric tension were recorded. The ring was stretched to an optimal baseline tension of $3 \mathrm{mN}$ and then allowed to equilibrate for $60 \mathrm{~min}$ before the start of the experiment. Each ring was first contracted by $60 \mathrm{mmol} / \mathrm{L} \mathrm{KCl}$ and rinsed in Krebs solution, and after wash out, phenylephrine $(1 \mu \mathrm{mol} / \mathrm{L})$ was used to produce a steady contraction and relaxed by cumulative additions of acetylcholine (ACh) $\left(10^{-8}\right.$ to $\left.10^{-5} \mathrm{~mol} / \mathrm{L}\right)$ in control or in the presence of $3 \mu \mathrm{mol} / \mathrm{L}$ losartan (ARB), $100 \mu \mathrm{mol} / \mathrm{L}$ apocynin [NAD(P)H oxidases inhibitor], or $100 \mu \mathrm{mol} / \mathrm{L}$ tempol [superoxide dismutase (SOD) mimetic]. These inhibitors had no effect on acetylcholine-induced relaxations in aortas from nondiabetic $\mathrm{db} / \mathrm{m}^{+}$ mice (data not shown). Endothelium-independent relaxations to sodium nitroprusside (SNP) $\left(10^{-9}\right.$ to $\left.10^{-6} \mathrm{~mol} / \mathrm{L}\right)$ were studied in rings without endothelium. Each experiment was performed on rings prepared from different mice.

Each human renal artery was cut into $2-3$ ring segments (2$3 \mathrm{~mm}$ in length) and each set of experiments were performed on rings from different human samples. Rings were suspended in organ baths as described previously (26). Each ring was initially stretched to an optimal tension of $25 \mathrm{mN}$ and then allowed to equilibrate for $90 \mathrm{~min}$ before the start of the experiment.

\section{Detection of intracellular ROS by dihydroethidium fluorescence}

The amount of intracellular ROS production was determined using dihydroethidium (DHE) (Molecular Probes, Eugene, OR), which binds to DNA when oxidized to emit fluorescence (33). Aortic rings from $d b / m^{+}$and $d b / d b$ mice were obtained as described above and treated with or without ACh. To investigate the inhibitory effects of the RAAS inhibitor on ROS production, aortas were exposed for $30 \mathrm{~min}$ to one of the inhibitors including losartan, apocynin, or tempol before the addition of $\mathrm{ACh}$, as to mimic the conditions in the functional study. To verify the contribution of ROS production from endothelium, the endothelial layer was removed by rolling the luminal surface with the tip of a pair of fine forceps. To examine the role of extracellular calcium ions on the generation of ROS, calcium-free Krebs solution was prepared to incubate the aortic rings for $30 \mathrm{~min}$ before the addition of ACh. Frozen sections of the aortic ring were cut in $10-\mu \mathrm{m}$ thickness using cryostat and incubated for $10 \mathrm{~min}$ at $37^{\circ} \mathrm{C}$ in Krebs solution containing $5 \mu \mathrm{mol} / \mathrm{L}$ DHE. Fluorescent intensity was measured by confocal microscope (FV1000, Olympus, Tokyo, Japan) at excitation/emission of $488 / 605 \mathrm{~nm}$ to visualize the signal. The images were analyzed by the Fluoview software (Olympus).

\section{Immunohistochemical staining of Ang II}

Aortic rings were fixed in $4 \%$ paraformaldehyde at $4{ }^{\circ} \mathrm{C}$ overnight, dehydrated, processed, and embedded in paraffin. Cross sections at $5 \mu \mathrm{m}$ were cut on microtome (Leica Microsystems, Wetzlar, Germany). After rehydrated to water, sections were microwave boiled in $0.01 \mathrm{~mol} / \mathrm{L}$ citrate buffer $(\mathrm{pH}$ 6.0) for $10 \mathrm{~min}$ for antigen retrieval, then incubated for $15 \mathrm{~min}$ with $3 \% \mathrm{H}_{2} \mathrm{O}_{2}$ at room temperature to block endogenous peroxidase activity. After washed with phosphate buffer saline (PBS), sections were blocked in 5\% normal goat or donkey serum according to the host species (Jackson Immunoresearch, West Grove, PA) for $1 \mathrm{~h}$ at room temperature. Primary antibody (anti-Ang II, 1:500, Peninsula laboratory, 
Table 1. Basic Parameters in $D B / M^{+}$Control, $D B / D B$, and $D B / D B$ Mice Chronically Treated WITH VALSARTAN OR ENALAPRIL

\begin{tabular}{|c|c|c|c|c|}
\hline Parameter & $\mathrm{db} / \mathrm{m}^{+}$ & $\mathrm{db} / \mathrm{db}$ & $\begin{array}{l}\mathrm{db} / \mathrm{db}+ \\
\text { Valsartan }\end{array}$ & $\begin{array}{l}\mathrm{db} / \mathrm{db}+ \\
\text { Enalapril }\end{array}$ \\
\hline Body weight, g & $26.6 \pm 1.5$ & $55.7 \pm 1.7^{*}$ & $52.8 \pm 1.4^{*}$ & $55.7 \pm 2.8^{*}$ \\
\hline Blood pressure, $\mathrm{mmHg}$ & $92.6 \pm 1.6$ & $127.3 \pm 3.9^{*}$ & $102.6 \pm 4.3^{\#}$ & $93.0 \pm 1.9^{\#}$ \\
\hline Plasma level of Glucose (fasting), $\mathrm{mmol} / \mathrm{L}$ & $5.2 \pm 2.2$ & $17.0 \pm 3.7^{*}$ & $14.0 \pm 1.6^{*}$ & $15.1 \pm 1.6^{*}$ \\
\hline Insulin, $\mathrm{ng} / \mathrm{mL}$ & $1.4 \pm 0.12$ & $24.6 \pm 3.5^{*}$ & $26.2 \pm 4.4^{*}$ & $25.8 \pm 5.1^{*}$ \\
\hline Total cholesterol, mg/dl & $75.7 \pm 2.4$ & $133.1 \pm 6.4^{*}$ & $97.5 \pm 3.7^{\#}$ & $113.9 \pm 5.3^{\#}$ \\
\hline Triglyceride, $\mathrm{mg} / \mathrm{dl}$ & $86.5 \pm 5.2$ & $184.3 \pm 15^{*}$ & $174.7 \pm 10^{*}$ & $166.3 \pm 13^{*}$ \\
\hline
\end{tabular}

Results are means \pm SEM of measurements from $6-8$ different mice. ${ }^{*} p<0.05$ relative to $d b / m^{+}$group; ${ }^{\#} p<0.05$ relative to $d b / d b$ group.

Belmont, CA, and anti-eNOS, 1:200, Santa Cruz, CA) diluted in normal serum were incubated overnight at $4{ }^{\circ} \mathrm{C}$. The slides were washed with PBS three times ( 5 min each). Biotin-SP conjugated goat anti-rabbit secondary antibodies (1:500, Jackson Immunoresearch) diluted in PBS were added and incubated for $1 \mathrm{~h}$ at room temperature. Slides were washed with PBS three times (5 min each) and incubated for $30 \mathrm{~min}$ with streptavidin-HRP conjugate (1:500, Zymed laboratory, San Francisco, CA) at room temperature, and washed. Positive staining was developed as brown precipitate by $3,3^{\prime}-$ diamonobenzidine tetrachloride (DAB) chromogen substrate (Vector laboratory, Burlingame, CA). Slides were rinsed with water and counterstained with hematoxylin. Pictures were taken under Leica DMRBE microscope with a SPOT-RT digital camera and SPOT Advanced software (Diagnostic Instruments, Sertling Heights, MI) and intensities of signals were analyzed by ImageJ (National Institute of Health, Bethedsa, MD).

\section{Western blot analysis}

Protein samples prepared from aorta homogenates were electrophoresed through a 10\% SDS-poly-acrylamide gel, transferred onto an immobilon-P polyvinylidene difluoride membrane (Millipore Corp., Bedford, MA). Nonspecific binding sites were blocked with $5 \%$ nonfat milk or $1 \%$ BSA in $0.05 \%$ Tween-20 PBS. The blots were incubated overnight at $4{ }^{\circ} \mathrm{C}$ with the primary antibodies: monoclonal anti- $\mathrm{AT}_{1} \mathrm{R}$, polyclonal anti- $\mathrm{AT}_{2} \mathrm{R}$ (1:1000, Abcam, Cambridge, UK); monoclonal anti-nitrotyrosine (1:2000, Abcam), polyclonal anti-phosphor-eNOS Ser ${ }^{1177}$ (1:1000, Upstate Biotechnology, Lake Placid, NY); polyclonal anti-ACE, anti-eNOS, antip22 ${ }^{\text {phox }}$ and anti-p47 $7^{\text {phox }}$ (1:1000, Santa Cruz); monoclonal anti-phosphor-p38 MAPK (Thr180/Tyr182), polyclonal antip38 MAPK, monoclonal anti-phospho-p44/42 MAPK (ERK1/2) (Thr202/Tyr204), monoclonal anti-p44/42 MAPK (Cell Signaling, Beverly, MA), followed by HRP-conjugated
FIG. 1. Valsartan or enalapril treatment improved endothelial function in $d b / d b$ mice. Chronic treatment for 6 weeks with valsartan $\left(\mathrm{AT}_{1} \mathrm{R}\right.$ blocker, $10 \mathrm{mg} / \mathrm{kg} /$ day) or enalapril (ACE inhibitor, $10 \mathrm{mg} / \mathrm{kg} /$ day) improved endothelial function, as shown by representative records (A) and concentration-response curves $(B, C)$. Data are means \pm SEM; $n=$ $7-8 ;{ }^{* * *} p<0.001$ relative to $d b / d b$. Phe, phenylephrine.
A
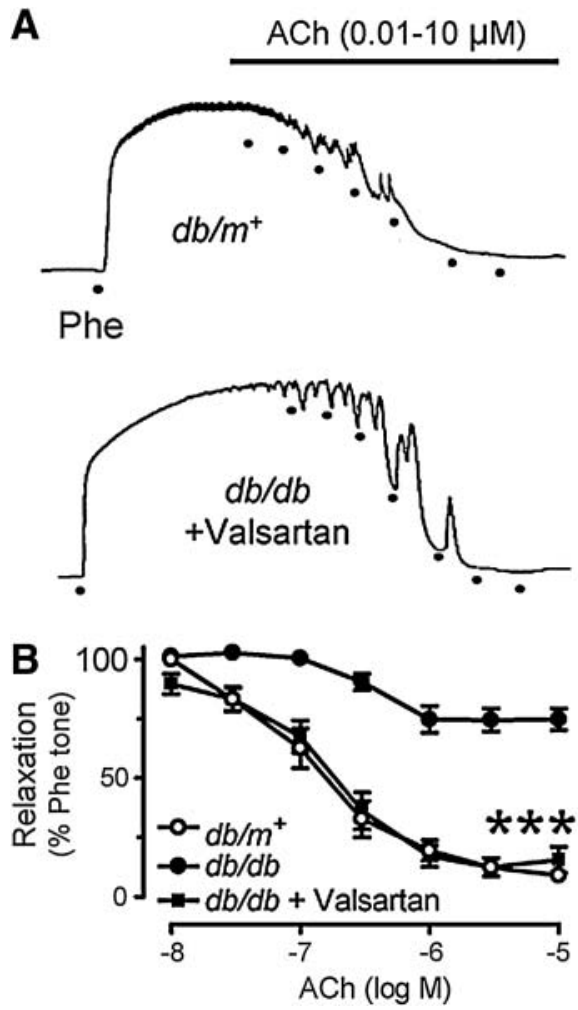
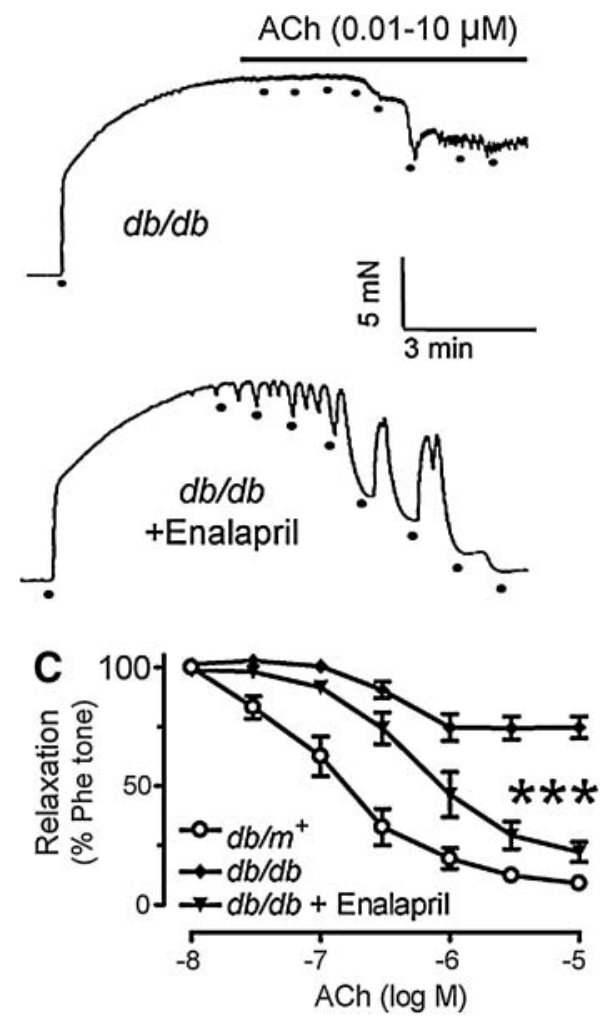
secondary antibody (DakoCytomation, Carpinteria, CA). Monoclonal anti- $\beta$-actin (1:5000, Abcam) was used as a housekeeping protein. Densitometry was performed using a documentation program (Flurochem, Alpha Innotech Corp., San Leandro, CA).

\section{Organ culture of mouse arterial rings in high glucose medium}

High glucose $(30 \mathrm{mmol} / \mathrm{L})$ and mannitol (osmotic control) solutions were prepared in Dulbeco's Modified Eagle's Media (DMEM, Gibco, Gaithersberg, MD) culture media supplemented with $10 \%$ fetal bovine serum (FBS, Gibco), plus $100 \mathrm{IU} / \mathrm{ml}$ penicillin and $100 \mu \mathrm{g} / \mathrm{ml}$ streptomycin. Mouse thoracic aortic rings ( $2 \mathrm{~mm}$ in length) were then incubated in four groups, including $5 \mathrm{mmol} / \mathrm{L}$ glucose alone (NG), $5 \mathrm{mmol} / \mathrm{L}$ glucose plus $25 \mathrm{mmol} / \mathrm{L}$ mannitol (M), $30 \mathrm{mmol} / \mathrm{L}$ glucose (HG), $30 \mathrm{mmol} / \mathrm{L}$ glucose plus $3 \mu \mathrm{mol} / \mathrm{L}$ losartan $\left(\mathrm{HG}+\right.$ losartan) for $36 \mathrm{~h}$ in an incubator kept at $37^{\circ} \mathrm{C}$. After the incubation period, the segments were transferred to fresh Krebs solution, mounted in a myograph, and changes in arterial tone were recorded.

\section{Drugs and solutions}

Acetylcholine, $\mathrm{N}^{\mathrm{G}}$-nitro-L-arginine methyl ester (L-NAME), phenylephrine, angiotensin II, sodium nitroprusside (SNP), diphenyliodonium, and tempol were purchased from SigmaAldrich Chemical (St Louis, MO). Apocynin was from Calbiochem (San Diego, CA). Losartan was purchased from Cayman (Ann Arbor, MI). Besides losartan, apocynin and diphenyliodonium were dissolved in DMSO (Sigma-Aldrich), all other drugs were dissolved in double-distilled water. Krebs solution contained (mmol/L): $119 \mathrm{NaCl}, 4.7 \mathrm{KCl}, 2.5 \mathrm{CaCl}_{2}, 1$ $\mathrm{MgCl}_{2}, 25 \mathrm{NaHCO}_{3}, 1.2 \mathrm{KH}_{2} \mathrm{PO}_{4}$, and 11 D-glucose. A Ca ${ }^{2+}$ free solution was identical to Krebs solution with exclusion of $\mathrm{Ca}^{2+}$ and addition of $2 \mathrm{mmol} / \mathrm{L}$ EGTA.

\section{Statistical analysis}

Results were means \pm SEM from different mice or human subjects. Concentration-response curves were analyzed by nonlinear regression curve fitting using GraphPad Prism software (Version 4.0, San Diego, CA) to approximate $\mathrm{E}_{\max }$ as the maximal response and $\mathrm{pIC}_{50}$ as the negative logarithm of the drug concentration that produced $50 \%$ of $\mathrm{E}_{\max }$. These values are summarized in Supplemental Table 1 (see www.liebert online.com/ars) for relaxant responses in both mouse and human arteries. Statistical significance was determined by twotailed Student's $t$-test or one-way ANOVA followed by Bonferroni post-tests when more than two treatments were compared. $P<0.05$ was regarded as significantly different.

\section{Results}

\section{Basic metabolic parameters}

Body weight of $d b / d b$ mice increased gradually from 4 to 16 weeks when compared with age-matched $\mathrm{db} / \mathrm{m}^{+}$lean control mice (Supplemental Fig. 1A; see www.liebertonline.com/ars). Valsartan or enalapril treatment for 6 weeks did not alter body weight of $d b / d b$ mice (Table 1 ). Oral glucose tolerance test revealed a progressive impairment in glucose sensitivity (Supplemental Fig. 1B; see www.liebertonline.com/ars) in $d b / d b$ mice. The levels of fasting blood glucose and plasma insulin were higher in $d b / d b$ mice than $d b / m^{+}$mice and these values were unaffected by valsartan or enalapril treatment (Table 1). However, treatment with valsartan and enalapril both improved glucose tolerance (Supplemental Figs. 2A-2C; see www.liebertonline.com/ars). Blood pressure of $d b / d b$ mice $\left(127.3 \pm 3.9 \mathrm{mmHg}, P<0.05 \mathrm{vs} d b / \mathrm{m}^{+}\right)$was higher than that of $\mathrm{db} / \mathrm{m}^{+}$mice $(92.6 \pm 1.6 \mathrm{mmHg})$ which was reduced by valsartan $(102.6 \pm 4.3 \mathrm{mmHg}, P<0.05$ vs $d b / d b)$ or enalapril $(93.0 \pm 1.9$ $\mathrm{mmHg}, P<0.05$ vs $d b / d b$ ) treatment (Table 1 and Supplemental
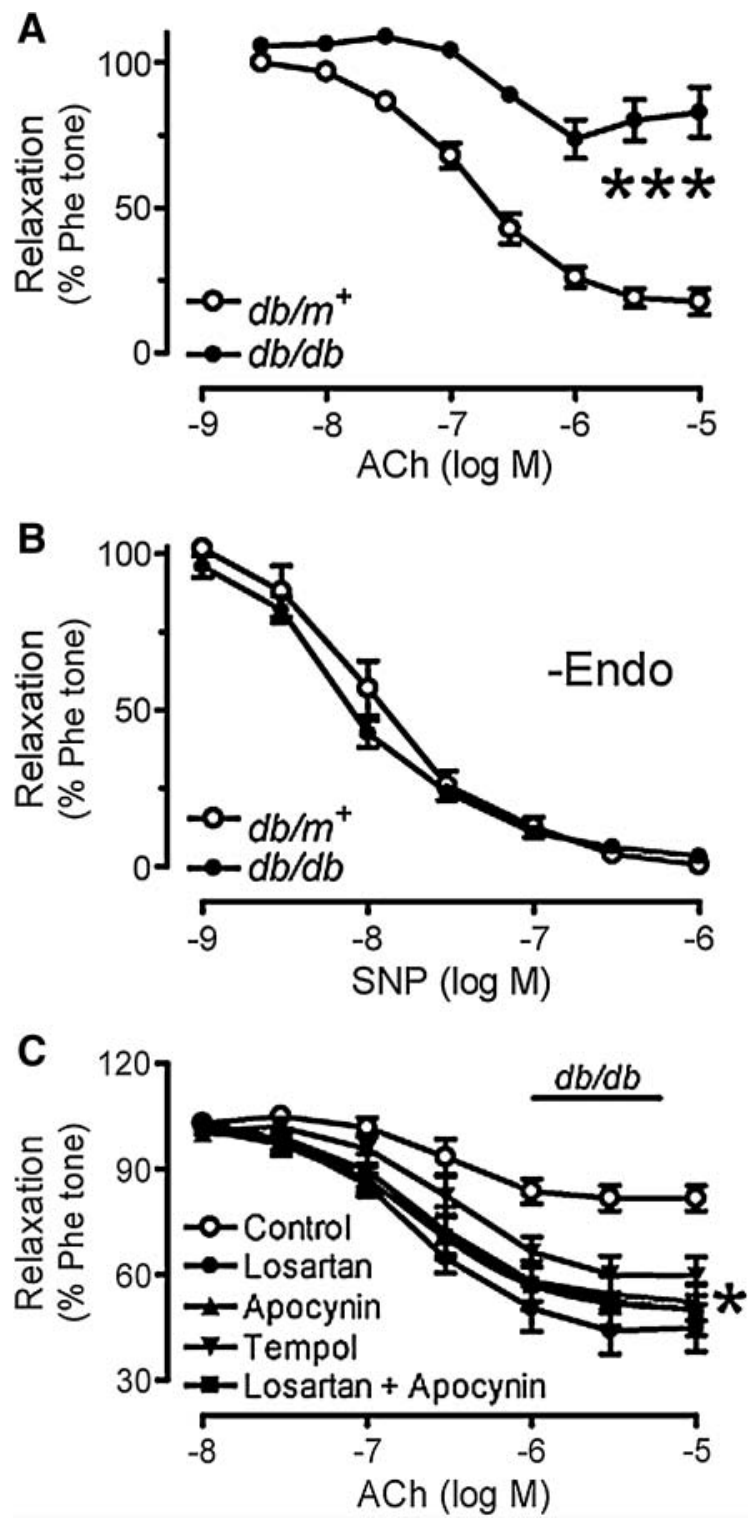

FIG. 2. Blockade of RAAS and associated oxidative stress improved endothelium-dependent dilatations in $d b / d b$ mouse aortas. (A) ACh-induced dilatations were impaired in $d b / d b(\mathrm{n}=6)$ compared with $d b / m^{+}$mouse aortas; whilst (B) SNP-induced endothelium-independent dilatation was comparable in both groups. Acute exposure of diabetic mouse aortas to (C) losartan $\left(3 \mu \mathrm{mol} / \mathrm{L}, \mathrm{AT}_{1} \mathrm{R}\right.$ blocker), apocynin $(100 \mu \mathrm{mol} / \mathrm{L}, \quad \mathrm{NAD}(\mathrm{P}) \mathrm{H}$ oxidase inhibitor), or tempol (100 $\mu \mathrm{mol} / \mathrm{L}$, ROS scavenger) enhanced ACh-induced dilatations. Combined treatment with losartan and apocynin had no further improvement (C). Data are means \pm SEM; $n=6-8$; ${ }^{* * *} p<0.001$ relative to $d b / m^{+}$and ${ }^{*} p<0.05$ relative to $d b / d b$. 
Fig. 2D; see www.liebertonline.com/ars). In addition, the elevated levels of plasma triglyceride in $d b / d b$ mice were insensitive to valsartan or enalapril treatment. By contrast, valsartan or enalapril treatment reversed the increased level of total cholesterol in $d b / d b$ mice (Table 1$)$.

\section{Improved endothelium-dependent dilatations in $d b / d b$ mouse aortas by RAAS blockade}

Six-week chronic treatment with valsartan or enalapril significantly improved endothelium-dependent dilatations in $d b / d b$ mouse aortas as shown in representative tracings (Figs. 1A-1C). ACh-induced endothelium-dependent dilatations were impaired in $d b / d b$ mouse aortas as compared with those of nondiabetic $\mathrm{db} / \mathrm{m}^{+}$mice (Figs. 1A and 2A), whilst sodium nitroprusside (SNP)-induced endothelium-independent dilatations were comparable between the two groups (Fig. 2B). $\mathrm{AT}_{1} \mathrm{R}$ blockade by losartan $(3 \mu \mathrm{mol} / \mathrm{L}, 30-\mathrm{min}$ incubation $)$ (Fig. 2C) and inhibition of NAD(P)H oxidases by apocynin (100 $\mu \mathrm{mol} / \mathrm{L}$, Fig. 2C) improved ACh-induced vasodilatations, whilst combination of losartan and apocynin (Fig. 2C) did not cause further improvement (Supplemental Table 1). SOD mimetic tempol $(100 \mu \mathrm{mol} / \mathrm{L}$, Fig. $2 \mathrm{C})$ also enhanced the blunted dilatations to $\mathrm{ACh}$ in $d b / d b$ mouse aortas.
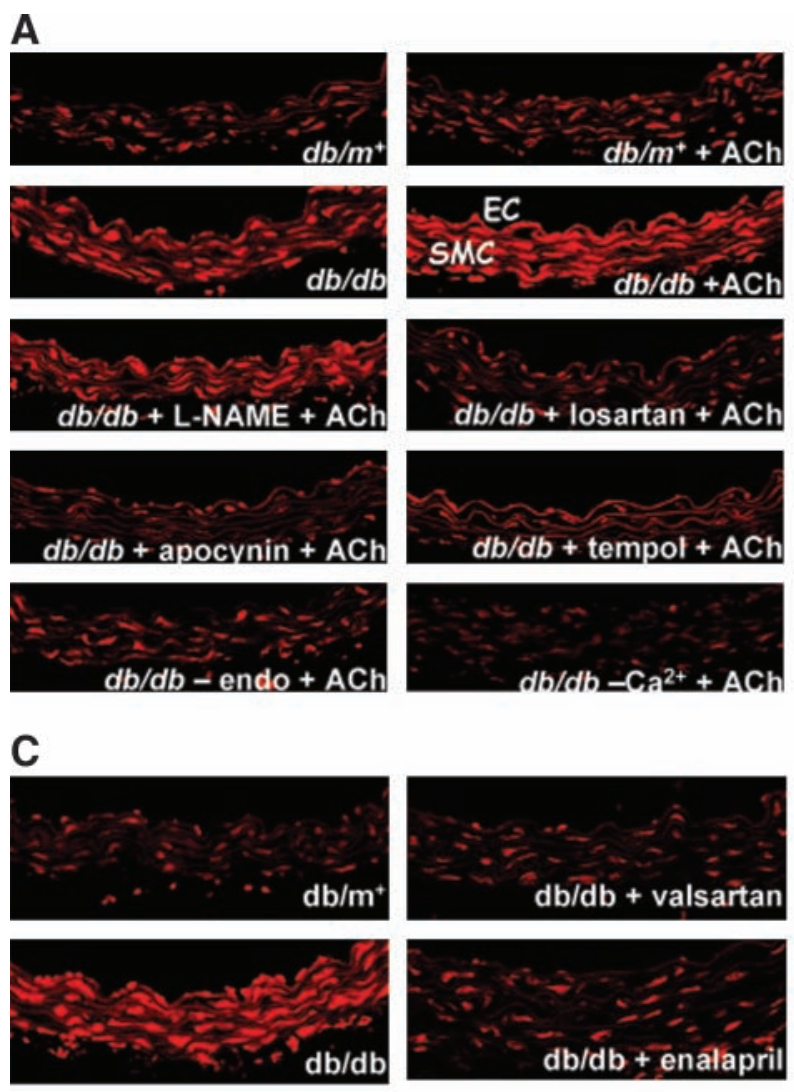

Augmented ROS production in $d b / d b$ mouse aortas mediated by $A T_{1} R$

The basal level of ROS reflected by the intensity of dihydroethidium (DHE) fluorescence was much higher in the wall of $d b / d b$ mouse aortas (Fig. 3). The ROS level markedly increased in response to ACh $(10 \mu \mathrm{mol} / \mathrm{L})$, but to a greater extent in $d b / d b$ mouse aortas (Figs. 3A and 3B). Acute exposure of $d b / d b$ mouse aortas to L-NAME $(100 \mu \mathrm{mol} / \mathrm{L})$ attenuated ACh-stimulated rises in ROS. The increased ROS generation was eliminated by $30-\mathrm{min}$ treatment with losartan $(3 \mu \mathrm{mol} / \mathrm{L})$, apocynin $(100 \mu \mathrm{mol} / \mathrm{L})$, or tempol $(100 \mu \mathrm{mol} / \mathrm{L})$ (Figs. 3A and 3B). Furthermore, the ACh-stimulated ROS increase was greatly diminished in the absence of extracellular $\mathrm{Ca}^{2+}$ ions or in aortas without endothelium (Figs. 3A and 3B). Increased ROS production in $d b / d b$ mouse aortas was also abolished by chronic valsartan or enalapril treatment (Figs. 3C and 3D).

\section{Effects of RAAS blockade on local production of Ang II in the vascular wall}

Increased Ang II staining was observed in the vascular wall of aortas from $d b / d b$ mice compared with $d b / m^{+}$control (Figs. $4 \mathrm{~A}$ and $4 \mathrm{~B})$, accompanied by ACE upregulation (Fig. 4C).
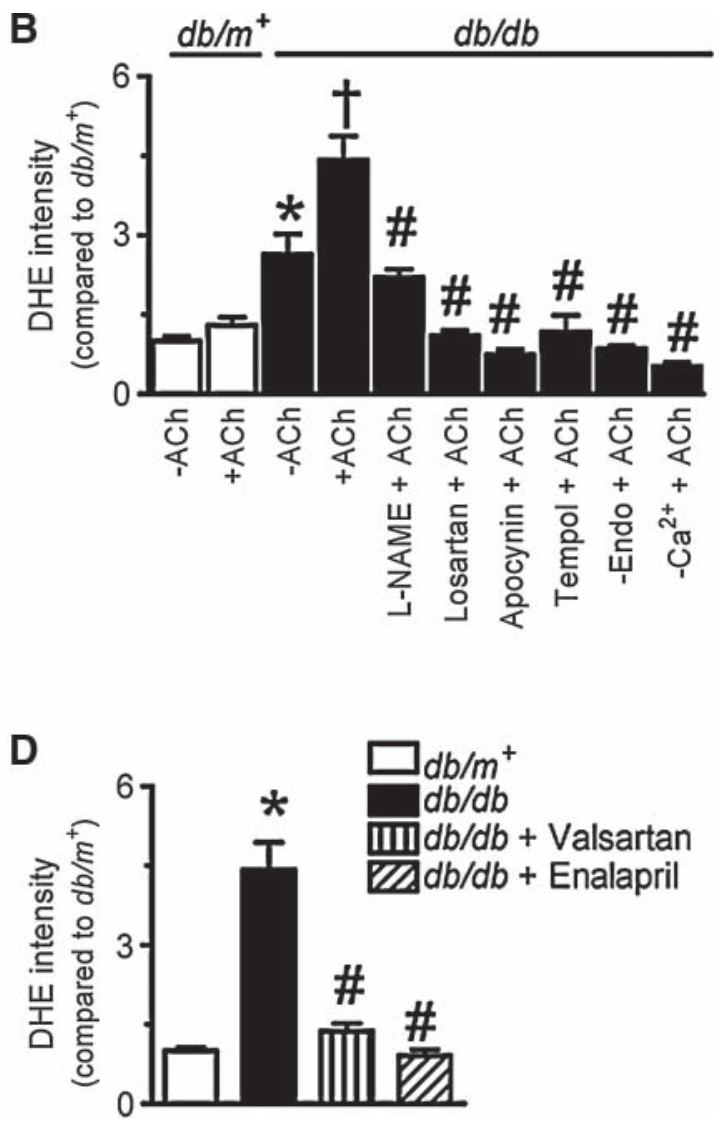

FIG. 3. $\quad \mathrm{AT}_{\mathbf{1}} \mathbf{R}$ mediated ROS production in $d b / d b$ mouse aortas. (A) Addition of $\mathrm{ACh}(+\mathrm{ACh})$ increased ROS production in $d b / d b$ mouse aortas without an effect in nondiabetic mouse aortas. The ROS increase was inhibited by L-NAME, and eliminated by acute exposure to losartan, apocynin, or tempol. ACh failed to trigger ROS increase in $d b / d b$ mouse aortas without endothelium (-Endo), or with endothelium but in the absence of extracellular $\mathrm{Ca}^{2+}$ ions $\left(-\mathrm{Ca}^{2+}\right)$. (B) Summarized data of DHE fluorescence intensity under different pharmacological interventions. (C, D) Chronic RAAS inhibition also prevented the increased ROS production in $d b / d b$ mouse aortas reflected by DHE fluorescence. Data are means \pm SEM; $n=4-6$; ${ }^{*} p<0.05$ relative to $d b / m^{+}-\mathrm{Ach} ;{ }^{\dagger} p<0.05 \mathrm{vs} d b / d b-$ Ach; ${ }^{\#} p<0.05$ relative to $d b / d b+$ ACh. (For interpretation of the references to color in this figure legend, the reader is referred to the web version of this article at www.liebertonline.com/ars). 
A

A

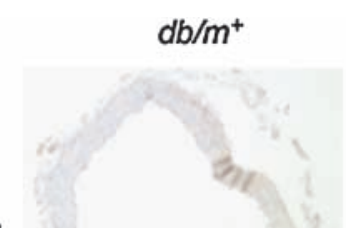

Ang II
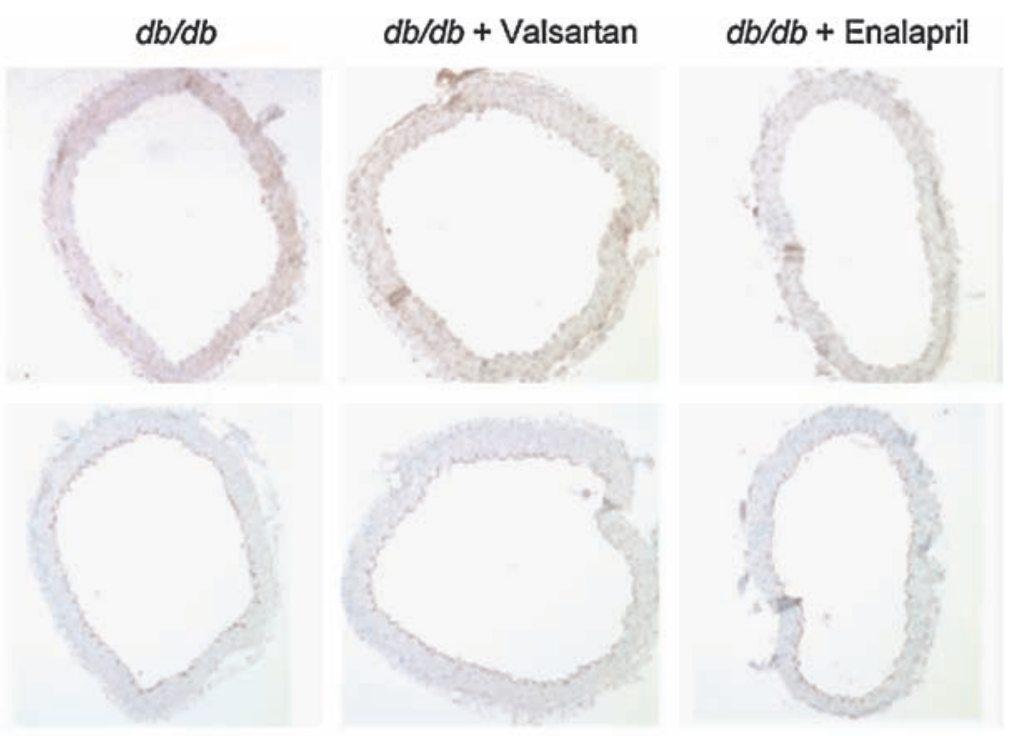

B

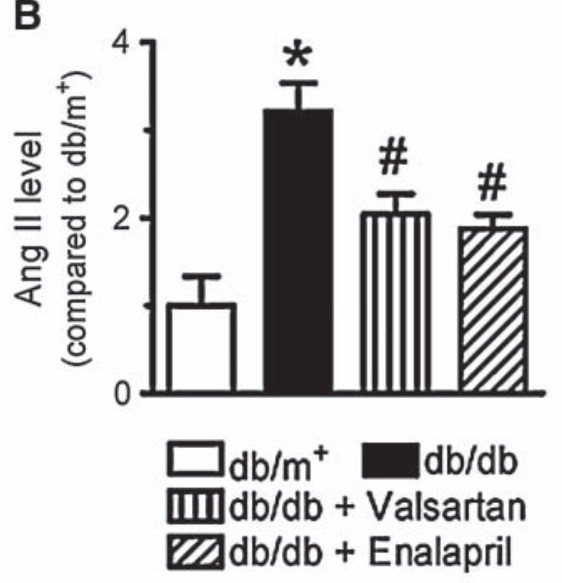

C

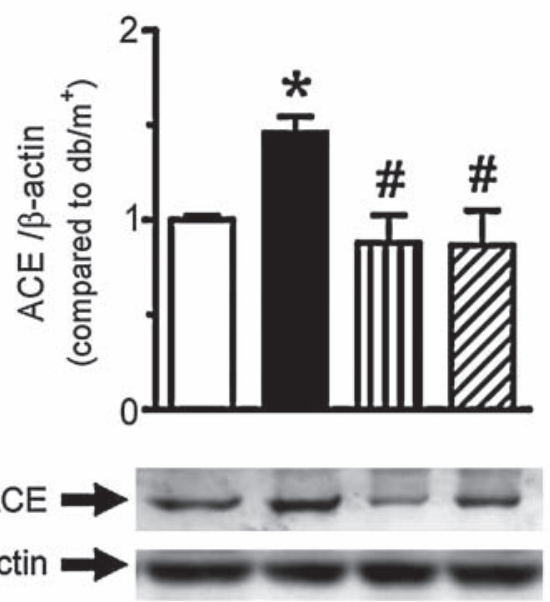

FIG. 4. Enhanced angiotensin II production in diabetic aortic vascular wall prevented by chronic valsartan or enalapril treatment. (A) Representative pictures showing Ang II immunostaining in mouse aortas from $d b / m^{+}, d b / d b, d b / d b$ treated with valsartan, and $d b / d b$ treated with enalapril. eNOS immunostaining was used to show the endothelial layer. (B) Summarized figures for Ang II staining in different groups of mice. (C) Western blot analysis demonstrating increased in angiotensin converting enzyme (ACE) expression lowered by valsartan or enalapril chronic treatment. Data are means \pm SEM of 4 experiments. Statistical significance is indicated by ${ }^{*} p<0.05$ relative to $d b / m^{+}$and ${ }^{\#} p<0.05$ relative to $d b / d b$. (For interpretation of the references to color in this figure legend, the reader is referred to the web version of this article at www.liebertonline.com/ars).

Chronic RAAS blockade normalized the ACE expression and tissue Ang II levels (Figs. 4A-4C).

\section{Western blot analysis of $A T_{1} R, A T_{2} R, p 22^{\text {phox }}$, $p 47^{\text {phox }}$, nitrotyrosine, eNOS, and p-eNOS}

Immunoblotting showed that a significantly increased expression of $\mathrm{AT}_{1} \mathrm{R}$ in $d b / d b$ mouse aortas was normalized by valsartan or enalapril treatment (Fig. $5 \mathrm{~A}$ ) while $\mathrm{AT}_{2} \mathrm{R}$ expression remained unaffected (Supplemental Fig. 3B; see www.liebertonline.com/ars). Ang II also induced a greater vasoconstriction in $d b / d b$ mouse aortas that were prevented by valsartan or enalapril treatment (Supplemental Fig. 3C; see www.liebertonline.com/ars). In addition, chronic therapy with valsartan or enalapril reduced the increased level of $\mathrm{NAD}(\mathrm{P}) \mathrm{H}$ oxidase subunits p22 ${ }^{\text {phox }}$ (Fig. 5B) and p47 $7^{\text {phox }}$ (Fig. $5 \mathrm{C})$. The elevated nitrotyrosine levels in $d b / d b$ mouse aortas were also reversed by the treatment with valsartan or enalapril (Fig.
5D). The reduced phosphorylation of eNOS at Ser ${ }^{1177}$ in $d b / d b$ mouse aortas could not be reversed by RAAS blockade, while total eNOS protein expression remained unchanged (Supplemental Fig. 4; see www.liebertonline.com/ars).

\section{Impaired endothelium-dependent relaxations in renal arteries from diabetic patients rescued by $A T_{1} R$ blockade}

Renal arteries obtained from diabetic patients relaxed significantly less in response to ACh than those from nondiabetic subjects (Figs. 6A and 6B). Acute exposure to losartan $(3 \mu \mathrm{mol} / \mathrm{L})$ for 30 min markedly enhanced the ACh-induced relaxations in diabetic human renal arteries (Fig. 6C) without affecting relaxations in nondiabetic human renal arteries (Fig. 6D). Renal arteries from diabetic patients have significantly higher $A_{1} R$ expression as compared with those from nondiabetic control (Fig. 6E, Supplemental Fig. 5; see www.liebertonline.com/ars). 
FIG. 5. RAAS inhibition attenuated the upregulation of protein expression of RAAS components. (A) Upregulated $\mathrm{AT}_{1} \mathrm{R}(60 \mathrm{kDa})$ expression, elevated NAD $(\mathrm{P}) \mathrm{H}$ oxidases subunits p22 $2^{\text {phox }}(22 \mathrm{kDa})(\mathbf{B})$, and $\mathrm{p} 47^{\text {phox }}(47 \mathrm{kDa})(\mathrm{C})$, in diabetic mouse aortas were normalized by chronic treatment with valsartan or enalapril. The increased nitrotyrosine $(60 \mathrm{kDa})$ formation in $d b / d b$ mouse aortas was reduced by RAAS inhibitors (D); $n=4 ;{ }^{*} p<0.05$ relative to $\mathrm{db} / \mathrm{m}^{+} ;{ }^{\#} p<0.05$ relative to $d b / d b$.
A

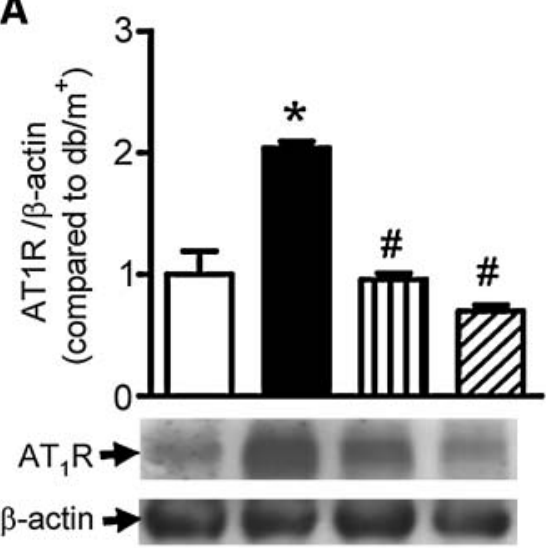

C

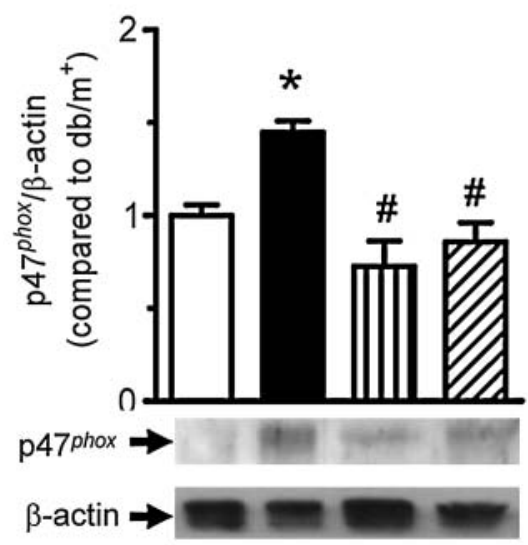

B

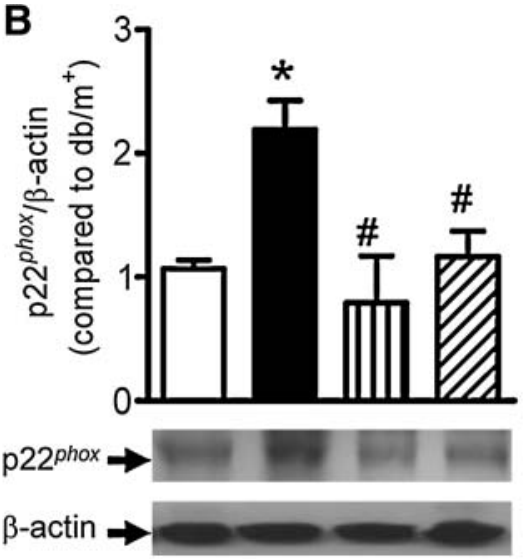

D

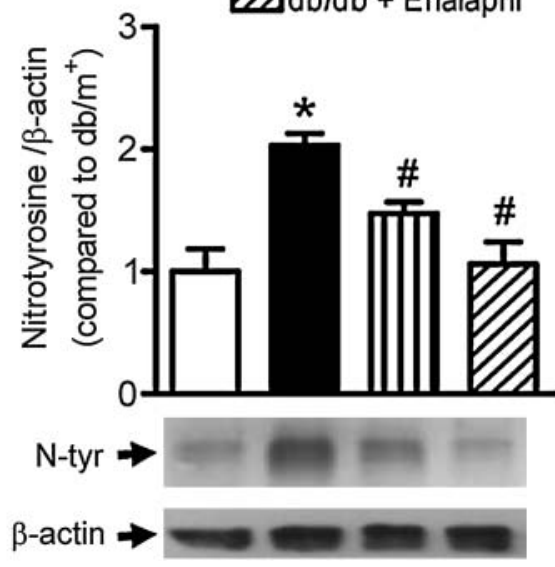

High glucose-induced endothelial dysfunction mediated by $A T_{1} R$

Chronic exposure $(36 \mathrm{~h})$ of nondiabetic mouse aortas to high glucose $(30 \mathrm{mmol} / \mathrm{L})$, but not to mannitol resulted in impaired ACh-induced dilatations (Fig. 7A), whilst SNPinduced endothelium-independent relaxations were unaffected (Fig. 7B). The presence of losartan $(3 \mu \mathrm{mol} / \mathrm{L})$ prevented the impairment of ACh-induced dilatations in high glucosetreated aortic rings (Fig. 7C). Likewise, losartan inhibited high glucose-stimulated increase in ROS production in the aortic wall (Fig. 7E). Losartan also restored ACh-induced dilatations which were impaired by 12-h incubation with Ang II $(100 \mathrm{nmol} / \mathrm{L})$ in nondiabetic mouse aortas (Fig. 7D).

\section{Discussion}

Our results clearly show a key role for $\mathrm{AT}_{1} \mathrm{R}$-mediated ROS overproduction in the diminished NO bioavailability which accounts for the impairment of ACh-induced endotheliumdependent dilatations in $d b / d b$ mouse aortas. Chronic administration of valsartan (ARB) or enalapril (ACE inhibitor) to 12-week old diabetic $d b / d b$ mice prevents impaired endothelium-dependent dilatations, which correlates with marked downregulation of $\mathrm{AT}_{1} \mathrm{R}$ expression and reduction in ROS production. Further supporting evidence comes from our demonstration that acute exposure to inhibitors of RAAS- oxidative stress axis (losartan, apocynin, or tempol) improves endothelium-dependent dilatations in $d b / d b$ mouse aortas and inhibits the ACh-stimulated ROS production. Importantly, losartan can also reverse the impaired endothelium-dependent relaxations in renal arteries from patients with diabetes. To further substantiate these findings, we also demonstrate that losartan is able to reverse the impaired dilatation that is induced by 36-h exposure of nondiabetic mouse aortas to high glucose $(30 \mathrm{mmol} / \mathrm{L})$; implicating that hyperglycaemiainduced increase in ROS generation requires $\mathrm{AT}_{1} \mathrm{R}$ activation. Taken together, the results of the present investigation support and further define the critical role of $\mathrm{AT}_{1} \mathrm{R}$ as the therapeutic target for alleviation of endothelial dysfunction and associated vascular events in diabetes.

The effect of RAAS blockade has been tested in various animal models of diabetes related vascular dysfunction. ACE inhibitors such as perindopril, zofenopril, and enalapril can prevent atherosclerosis progression in diabetic apoE-deficient mice $(10,25)$ by decreasing Ang II and increasing bradykinin. ACE inhibitors also restore vascular reactivity in type I diabetic mice (5). Likewise, ARBs such as candesartan, irbesartan, and valsartan also showed effectiveness in attenuating diabetes-associated atherosclerosis, retinopathy, and nephropathy through inhibiting advanced glycation, oxidative stress, and inflammatory cytokines $(9,10,49)$. However, little information is available concerning the functional benefit of 
A Human arteries
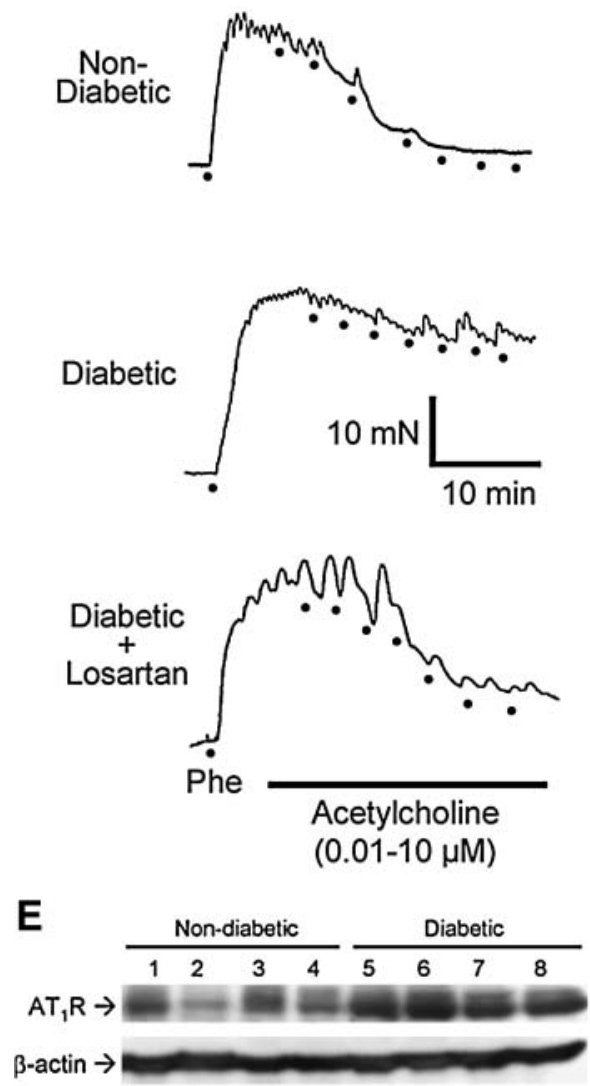
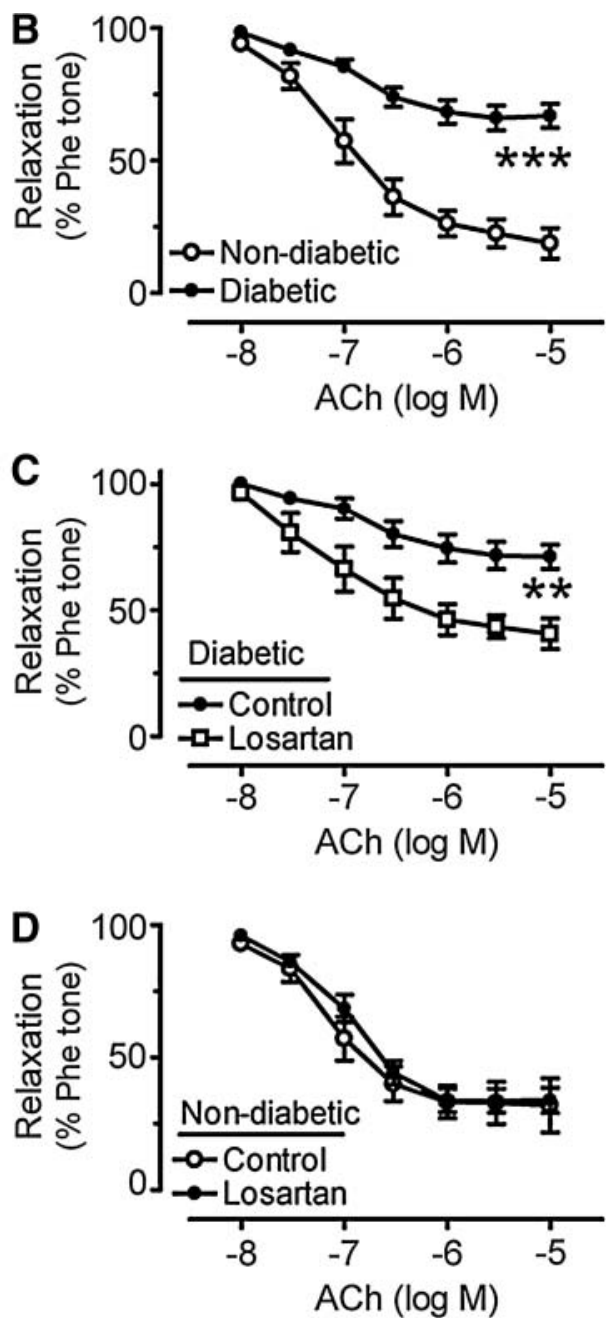

FIG. 6. Losartan improved endothelial function in renal arteries from diabetic patients. Representative records for ACh-induced relaxations of human renal arteries (A). Endothelium-dependent relaxations were significantly impaired in diabetic patients $(n=5)$ as compared with nondiabetic patients $(n=6)$ (B). Acute exposure to losartan $(3 \mu \mathrm{mol} / \mathrm{L})$ improved the impaired ACh-induced relaxations in diabetic human renal arteries $(n=5)(C)$ without affecting relaxations in nondiabetic renal arteries (D). Upregulation of AT1R expression in renal arteries from diabetic patients as compared to nondiabetic control (E). Data are means \pm SEM. ${ }^{* * *} p<$ 0.001 relative to nondiabetic; ${ }^{* *} p<0.01$ relative to control.
RAAS blockade in blood vessels of $d b / d b$ mice. Previous clinical studies showed that $\mathrm{AT}_{1} \mathrm{R}$ blockade by losartan could improve endothelial dilator function in patients with type 1 and type 2 diabetes $(12,13)$. However, whether this protective effect is mediated through blood pressure-lowering effects or other specific mechanisms is not clear. Flammer et al. reported that losartan significantly improved endothelial function in type 2 diabetic patients with hypertension, which might be attributed to the antioxidative effect of ARB and was independent of its blood pressure-lowering action, as serum 8isoprostane (a marker of oxidative stress) was significantly lower in losartan group, regardless of blood pressure changes (17). These results show the importance of antioxidative aspect of RAAS blockade that may contribute to the vasoprotection. While the correction of hypertension by ACE inhibitors or ARBs may partly explain the observed improvement of endothelial function in $d b / d b$ mice, in the present study, we intend to investigate whether $\mathrm{AT}_{1} \mathrm{R}$ blockers could reverse the reduced vasodilatation in diabetic mice and diabetic patients through direct actions on the vascular wall.

The observation of impaired endothelium-dependent dilatations in $d b / d b$ mouse aortas is consistent with recently reported results $(29,50)$. We conclude that $A T_{1} R$ mediates the impaired vasodilatation in diabetes based on the following observations. First, acute exposure of diabetic mouse aortas to
ARB significantly enhances ACh-induced dilatations. Acute treatment with apocynin or tempol enhances the AChinduced dilatations to a similar extent. In addition, a combined treatment with losartan and apocynin does not produce additive effects, implicating that Ang II signaling involves sequential steps, initial stimulation of $\mathrm{AT}_{1} \mathrm{R}$ followed by activation of $\mathrm{NAD}(\mathrm{P}) \mathrm{H}$ oxidases instead of independent actions. As apocynin was found to act as an antioxidant at concentrations higher than $300 \mu \mathrm{mol} / \mathrm{L}(1,20)$, we used $100 \mu \mathrm{mol} / \mathrm{L}$ of apocynin in the present study. We have also demonstrated that the enhanced ROS generation in mouse aortas upon angiotensin II stimulation detected by DHE fluorescence dye was prevented by both the NADPH oxidase inhibitors while apocynin had no effect on hydrogen peroxide-stimulated ROS production (Supplemental Fig. 6; see www.liebertonline.com/ars). Another structurally different NADPH oxidase inhibitor diphenyliodonium at $0.1 \mu \mathrm{mol} / \mathrm{L}$ also improved the impaired relaxations in $\mathrm{db} / \mathrm{db}$ mouse aortas and reduced angiotensin II-stimulated ROS generation (Supplemental Fig. 7; see www.liebertonline.com/ars), further supporting a role of $\mathrm{NAD}(\mathrm{P}) \mathrm{H}$ oxidase-derived ROS. Second, losartan prevented the impaired vasodilatation and ROS production in wild-type mouse arteries induced by high glucose, indicating that a direct effect of hyperglycemia on vasculature also requires $\mathrm{AT}_{1} \mathrm{R}$ activation. Finally, we 

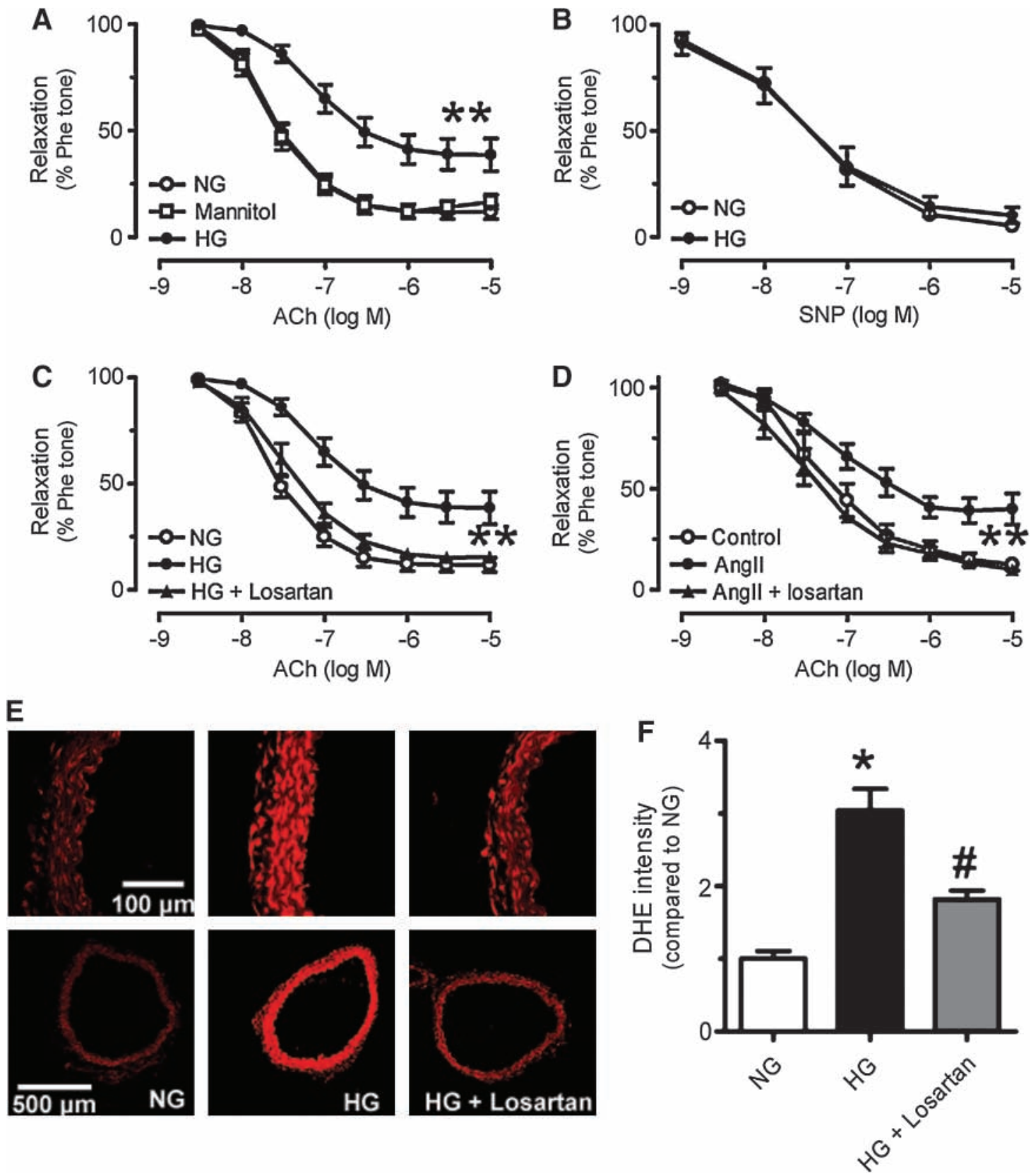

FIG. 7. Losartan prevented high glucose-induced endothelial dysfunction in nondiabetic mouse aortas. (A) Exposure to $30 \mathrm{mmol} / \mathrm{L}$ high glucose $(\mathrm{HG})$ for $36 \mathrm{~h}$ reduced endothelium-dependent dilatations as compared with normal glucose ( $5 \mathrm{mmol} / \mathrm{L}, \mathrm{NG})$ or mannitol ( $25 \mathrm{mmol} / \mathrm{L}$ mannitol plus $5 \mathrm{mmol} / \mathrm{L}$ glucose). (B) SNP-induced endothelium-independent dilatations were the same between the NG and HG groups. (C) Co-treatment with losartan $(3 \mu$ mol/L) significantly restored the impaired endothelial function. (D) Treatment with Ang II $(100 \mathrm{nmol} / \mathrm{L})$ impaired endothelium-dependent dilatations that were prevented by co-treatment with $3 \mu \mathrm{mol} / \mathrm{L}$ losartan. Data are means $\pm \mathrm{SEM} ; n=6-8$. Statistical significance between groups is indicated by ${ }^{* *} p<0.01$. (E, F) DHE fluorescence showed that high glucose enhanced ROS production in mouse aortas and losartan $(3 \mu \mathrm{mol} / \mathrm{L})$ blocked such effect $(n=4) ;{ }^{*} p<0.05$ relative to NG. $\# p<0.05$ relative to HG. (For interpretation of the references to color in this figure legend, the reader is referred to the web version of this article at www.liebertonline.com/ars).

demonstrated that Ang II impaired vasodilatation which was inhibited by losartan. To show the specificity of losartan on $\mathrm{AT}_{1} \mathrm{R}$ instead of possible ROS scavenging activity, the concentration $(3 \mu \mathrm{mol} / \mathrm{L})$ of losartan used in the functional study does not scavenge ROS generated by xanthine oxidase as indicated by electron paramagnetic resonance spectroscopy (Supplemental Fig. 8; see www.liebertonline.com/ars). Moreover, the reversal effect of losartan on high glucose- induced ROS overproduction is novel and this effect may help to elucidate more precise role of $\mathrm{AT}_{1} \mathrm{R}$ in hyperglycemiaassociated endothelial dysfunction in diabetes.

Chronic oral treatment with valsartan or enalapril markedly improves endothelium-dependent dilatations of $d b / d b$ mouse aortas. It is postulated that ROS derived from $\mathrm{AT}_{1} \mathrm{R}$-mediated NAD(P)H oxidases lowers the bioavailability of $\mathrm{NO}$ by either directly scavenging $\mathrm{NO}$ or by reducing 
the biosynthesis of NO catalyzed by endothelial nitric oxide synthase (eNOS). Our immunoblotting results clearly show that significant upregulations of $\mathrm{AT}_{1} \mathrm{R}$ and $\mathrm{NAD}(\mathrm{P}) \mathrm{H}$ oxidase subunits ( $\mathrm{p} 22^{\text {phox }}$ and $\mathrm{p} 47^{\mathrm{phox}}$ ) in $d b / d b$ mouse aortas can be normalized by chronic treatment with valsartan or enalapril, suggesting that RAAS blockade suppresses the stimulatory effect of Ang II on the expression and activity of $\mathrm{NAD}(\mathrm{P}) \mathrm{H}$ oxidases. $\mathrm{NAD}(\mathrm{P}) \mathrm{H}$ oxidase is the major source of ROS generation stimulated by Ang II, which is composed by membrane-bound gp $91^{\text {phox }}$ homolog (NOX1 in vascular smooth muscle cells and NOX2 in endothelial cells), catalytic subunit $\mathrm{p} 22^{\text {phox }}$, and regulatory subunits such as $\mathrm{p} 47^{\text {phox }}, \mathrm{p} 40^{\text {phox }}, \mathrm{p} 67^{\text {phox }}$, and $\operatorname{Rac} 1(3,28)$. In addition, the activation of p38 and extracellular signal-regulated kinase (ERK) 1/2 mitogen-activated protein kinase (MAPK) in $\mathrm{db} / \mathrm{db}$ mouse aortas was also inhibited by RAAS blockade (Supplemental Fig. 6). ROS stimulate the activation of MAPK pathways which further promote the expression of proinflammatory cytokines in endothelial cells (40), and ARBs can ameliorate diabetic glomerulopathy by suppressing MAPK activation (46). The inhibition of MAPK by RAAS blockade may also offer additional benefit in $d b / d b$ mice. In contrast, RAAS blockade did not reverse the reduced phosphorylation of eNOS at $\operatorname{Ser}^{1177}$ in $d b / d b$ mouse aortas (Supplemental Fig. 4), implicating that chronic RAAS blockade increased NO bioavailability by reducing oxidative stress rather than enhancing the NO production from eNOS (Supplemental Fig. 4). Although eNOS phosphorylation is known to decrease with prolonged oxidative stress (23), Ang II is reported to exert different effects, either increasing or decreasing eNOS phosphorylation $(38,39,48)$. However, we observed that RAAS blockade does not affect eNOS phosphorylation. The present findings further support the primary role of RAAS-dependent oxidative stress in endothelial dysfunction in diabetic mice.

The overproduction of ROS in diabetic mouse aortas, as reflected by increases in nitrotyrosine formation and DHE fluorescence intensity, is reversed by RAAS blockade. Similar to previous findings of eNOS uncoupling in diabetes $(22,31)$, we also confirmed this by showing that ACh stimulates further increase of ROS only in diabetic but not in nondiabetic mouse aortas, which is blocked by L-NAME or endothelium removal. More relevantly, we demonstrate that blockade of RAAS and associated oxidative stress by losartan, apocynin, or tempol, greatly reduces the ROS production upon stimulation of $\mathrm{ACh}$. These results indicate that ROS derived from $\mathrm{NAD}(\mathrm{P}) \mathrm{H}$ oxidases is likely required for stimulation of eNOS uncoupling to further increase intracellular ROS generation. In addition, we show that the release of ROS was dependent on the presence of extracellular $\mathrm{Ca}^{2+}$ ions which is in accordance with Guzik et al. who showed $\mathrm{Ca}^{2+}$ as an important intracellular activator of NAD $(\mathrm{P}) \mathrm{H}$ oxidases (18).

More significantly, we demonstrate a critical role of $\mathrm{AT}_{1} \mathrm{R}$ mediated ROS in impaired endothelium-dependent dilatations of human renal arteries. Renal arteries from diabetic patients have higher $\mathrm{AT}_{1} \mathrm{R}$ expression than nondiabetic control. Similar to $\mathrm{db} / \mathrm{db}$ mouse aortas, the impaired dilatations in human arteries from diabetic patients can also be effectively rescued by acute treatment with losartan, thus favoring the use of $\mathrm{AT}_{1} \mathrm{R}$ blockers for reversing endothelial dysfunction in patients with diabetes. In summary, the present study has provided scientific basis with novel evidence in support of clinical application of selective $\mathrm{AT}_{1} \mathrm{R}$ blockers for the prevention and treatment of diabetes-related vascular dysfunction.

\section{Acknowledgments}

This study was supported by Hong Kong Research Grant Council (CUHK 4653/08M and HKU 2/07C), CUHK Focused Investment Scheme, and CUHK Li Ka Shing Institute of Health Sciences.

\section{Author Disclosure Statement}

The authors have no competing financial interests to disclose.

\section{References}

1. Aldieri E, Riganti C, Polimeni M, Gazzano E, Lussiana C, Campia I, and Ghigo D. Classical inhibitors of NOX NAD(P)H oxidases are not specific. Curr Drug Metab 9: 686696, 2008

2. Banes-Berceli AK, Ketsawatsomkron P, Ogbi S, Patel B, Pollock DM, and Marrero MB. Angiotensin II and endothelin-1 augment the vascular complications of diabetes via JAK2 activation. Am J Physiol Heart Circ Physiol 293: H1291-1299, 2007.

3. Bendall JK, Rinze R, Adlam D, Tatham AL, de Bono J, Wilson N, Volpi E, and Channon KM. Endothelial Nox2 overexpression potentiates vascular oxidative stress and hemodynamic response to angiotensin II: Studies in endothelialtargeted Nox2 transgenic mice. Circ Res 100: 1016-1025, 2007.

4. Braga MF and Leiter LA. Role of renin-angiotensin system blockade in patients with diabetes mellitus. Am J Cardiol 104: 835-839, 2009.

5. Bucci M, Roviezzo F, Brancaleone V, Di Lorenzo A, Evangelista S, Gori M, and Cirino G. ACE-inhibition ameliorates vascular reactivity and delays diabetes outcome in NOD mice. Vascul Pharmacol 49: 84-90, 2008.

6. Burnier M and Zanchi A. Blockade of the renin-angiotensinaldosterone system: A key therapeutic strategy to reduce renal and cardiovascular events in patients with diabetes. J Hypertens 24: 11-25, 2006.

7. Cai H, Griendling KK and Harrison DG. The vascular $\mathrm{NAD}(\mathrm{P}) \mathrm{H}$ oxidases as therapeutic targets in cardiovascular diseases. Trends Pharmacol Sci 24: 471-478, 2003.

8. Cai H and Harrison DG. Endothelial dysfunction in cardiovascular diseases: The role of oxidant stress. Circ Res 87: 840-844, 2000.

9. Calkin AC, Giunti S, Sheehy KJ, Chew C, Boolell V, Rajaram YS, Cooper ME, and Jandeleit-Dahm KA. The HMG-CoA reductase inhibitor rosuvastatin and the angiotensin receptor antagonist candesartan attenuate atherosclerosis in an apolipoprotein E-deficient mouse model of diabetes via effects on advanced glycation, oxidative stress and inflammation. Diabetologia 51: 1731-1740, 2008.

10. Candido R, Allen TJ, Lassila M, Cao Z, Thallas V, Cooper $\mathrm{ME}$, and Jandeleit-Dahm KA. Irbesartan but not amlodipine suppresses diabetes-associated atherosclerosis. Circulation 109: 1536-1542, 2004.

11. Carr AA, Kowey PR, Devereux RB, Brenner BM, Dahlof B, Ibsen H, Lindholm LH, Lyle PA, Snapinn SM, Zhang Z, Edelman JM, and Shahinfar S. Hospitalizations for new heart failure among subjects with diabetes mellitus in the RENAAL and LIFE studies. Am J Cardiol 96: 1530-1536, 2005. 
12. Cheetham C, Collis J, O'Driscoll G, Stanton K, Taylor R, and Green D. Losartan, an angiotensin type 1 receptor antagonist, improves endothelial function in non-insulindependent diabetes. J Am Coll Cardiol 36: 1461-1466, 2000.

13. Collis J, Cheetham C, Dembo L, O'Driscoll J, Stanton K, Taylor R, and Green D. Losartan, an angiotensin type 1 receptor inhibitor, and endothelial vasodilator function in Type 1 diabetes mellitus. Diabet Med 17: 553-554, 2000.

14. Daly CA, Fox KM, Remme WJ, Bertrand ME, Ferrari R, and Simoons ML. The effect of perindopril on cardiovascular morbidity and mortality in patients with diabetes in the EUROPA study: Results from the PERSUADE substudy. Eur Heart J 26: 1369-1378, 2005.

15. De Vriese AS, Verbeuren TJ, Van de Voorde J, Lameire NH, and Vanhoutte PM. Endothelial dysfunction in diabetes. $\mathrm{Br} J$ Pharmacol 130: 963-974, 2000.

16. Didangelos TP, Arsos GA, Karamitsos DT, Athyros VG, Georga SD, and Karatzas ND. Effect of quinapril or losartan alone and in combination on left ventricular systolic and diastolic functions in asymptomatic patients with diabetic autonomic neuropathy. J Diabetes Comp 20: 1-7, 2006.

17. Flammer AJ, Hermann F, Wiesli P, Schwegler B, Chenevard R, Hurlimann D, Sudano I, Gay S, Neidhart M, Riesen W, Ruschitzka F, Luscher TF, Noll G, and Lehmann R. Effect of losartan, compared with atenolol, on endothelial function and oxidative stress in patients with type 2 diabetes and hypertension. J Hypertens 25: 785-791, 2007.

18. Guzik TJ, Chen W, Gongora MC, Guzik B, Lob HE, Mangalat D, Hoch N, Dikalov S, Rudzinski P, Kapelak B, Sadowski J, and Harrison DG. Calcium-dependent NOX5 nicotinamide adenine dinucleotide phosphate oxidase contributes to vascular oxidative stress in human coronary artery disease. J Am Coll Cardiol 52: 1803-1809, 2008.

19. Hadi HA and Suwaidi JA. Endothelial dysfunction in diabetes mellitus. Vasc Health Risk Manag 3: 853-876, 2007.

20. Heumuller S, Wind S, Barbosa-Sicard E, Schmidt HH, Busse $\mathrm{R}$, Schroder $\mathrm{K}$, and Brandes RP. Apocynin is not an inhibitor of vascular NADPH oxidases but an antioxidant. Hypertension 51: 211-217, 2008.

21. Higashi M, Shimokawa $H$, Hattori T, Hiroki J, Mukai $Y$, Morikawa K, Ichiki T, Takahashi S, and Takeshita A. Longterm inhibition of Rho-kinase suppresses angiotensin IIinduced cardiovascular hypertrophy in rats in vivo: Eeffect on endothelial NAD $(\mathrm{P}) \mathrm{H}$ oxidase system. Circ Res 93: 767775, 2003.

22. Hink U, Li H, Mollnau H, Oelze M, Matheis E, Hartmann M, Skatchkov M, Thaiss F, Stahl RA, Warnholtz A, Meinertz T, Griendling K, Harrison DG, Forstermann U, and Munzel T. Mechanisms underlying endothelial dysfunction in diabetes mellitus. Circ Res 88: E14-22, 2001.

23. $\mathrm{Hu} \mathrm{Z}$, Chen J, Wei Q, and Xia Y. Bidirectional actions of hydrogen peroxide on endothelial nitric-oxide synthase phosphorylation and function: Co-commitment and interplay of Akt and AMPK. J Biol Chem 283: 25256-25263, 2008.

24. Huang Y, Chan FL, Lau CW, Tsang SY, Chen ZY, He GW, and Yao X. Roles of cyclic AMP and $\mathrm{Ca} 2+$-activated $\mathrm{K}+$ channels in endothelium-independent relaxation by urocortin in the rat coronary artery. Cardiovasc Res 57: 824-833, 2003.

25. Jandeleit-Dahm K, Lassila M, Davis BJ, Candido R, Johnston CI, Allen TJ, Burrell LM, and Cooper ME. Anti-atherosclerotic and renoprotective effects of combined angiotensinconverting enzyme and neutral endopeptidase inhibition in diabetic apolipoprotein E-knockout mice. J Hypertens 23: 2071-2082, 2005.

26. Leung HS, Yao X, Leung FP, Ko WH, Chen ZY, Gollasch M, and Huang Y. Cilnidipine, a slow-acting $\mathrm{Ca} 2+$ channel blocker, induces relaxation in porcine coronary artery: Role of endothelial nitric oxide and [Ca2 + ]i. Br J Pharmacol 147: 55-63, 2006.

27. Malmberg K, Yusuf S, Gerstein HC, Brown J, Zhao F, Hunt D, Piegas L, Calvin J, Keltai M, and Budaj A. Impact of diabetes on long-term prognosis in patients with unstable angina and non-Q-wave myocardial infarction: results of the OASIS (Organization to Assess Strategies for Ischemic Syndromes) Registry. Circulation 102: 1014-1019, 2000.

28. Matsuno $K$, Yamada $H$, Iwata $K$, Jin D, Katsuyama M, Matsuki M, Takai S, Yamanishi K, Miyazaki M, Matsubara $\mathrm{H}$, and Yabe-Nishimura C. Nox1 is involved in angiotensin II-mediated hypertension: A study in Nox1-deficient mice. Circulation 112: 2677-2685, 2005.

29. Moien-Afshari F, Ghosh S, Khazaei M, Kieffer TJ, Brownsey RW, and Laher I. Exercise restores endothelial function independently of weight loss or hyperglycaemic status in $\mathrm{db} / \mathrm{db}$ mice. Diabetologia 51: 1327-1337, 2008.

30. O'Driscoll G, Green D, Maiorana A, Stanton K, Colreavy F, and Taylor R. Improvement in endothelial function by angiotensin-converting enzyme inhibition in non-insulindependent diabetes mellitus. J Am Coll Cardiol 33: 1506-1511, 1999.

31. Oak JH and Cai H. Attenuation of angiotensin II signaling recouples eNOS and inhibits nonendothelial NOX activity in diabetic mice. Diabetes 56: 118-126, 2007.

32. Patel A, MacMahon S, Chalmers J, Neal B, Woodward M, Billot L, Harrap S, Poulter N, Marre M, Cooper M, Glasziou P, Grobbee DE, Hamet P, Heller S, Liu LS, Mancia G, Mogensen CE, Pan CY, Rodgers A, and Williams B. Effects of a fixed combination of perindopril and indapamide on macrovascular and microvascular outcomes in patients with type 2 diabetes mellitus (the ADVANCE trial): A randomised controlled trial. Lancet 370: 829-840, 2007.

33. Robinson KM, Janes MS, Pehar M, Monette JS, Ross MF, Hagen TM, Murphy MP, and Beckman JS. Selective fluorescent imaging of superoxide in vivo using ethidiumbased probes. Proc Natl Acad Sci USA 103: 15038-15043, 2006.

34. Satoh M, Fujimoto $S$, Arakawa $S$, Yada T, Namikoshi T, Haruna Y, Horike H, Sasaki T, and Kashihara N. Angiotensin II type 1 receptor blocker ameliorates uncoupled endothelial nitric oxide synthase in rats with experimental diabetic nephropathy. Nephrol Dial Transplant 23: 3806-3813, 2008.

35. Savoia C, Touyz RM, Endemann DH, Pu Q, Ko EA, De Ciuceis C, and Schiffrin EL. Angiotensin receptor blocker added to previous antihypertensive agents on arteries of diabetic hypertensive patients. Hypertension 48: 271-277, 2006.

36. Schafer A, Flierl U, Vogt C, Menninger S, Tas P, Ertl G, and Bauersachs J. Telmisartan improves vascular function and reduces platelet activation in rats with streptozotocininduced diabetes mellitus. Pharmacol Res 56: 217-223, 2007.

37. Sodhi CP, Kanwar YS, and Sahai A. Hypoxia and high glucose upregulate AT1 receptor expression and potentiate ANG II-induced proliferation in VSM cells. Am J Physiol Heart Circ Physiol 284: H846-852, 2003.

38. Su KH, Tsai JY, Kou YR, Chiang AN, Hsiao SH, Wu YL, Hou $\mathrm{HH}$, Pan CC, Shyue SK, and Lee TS. Valsartan regulates the 
interaction of angiotensin II type 1 receptor and endothelial nitric oxide synthase via Src/PI3K/Akt signalling. Cardiovasc Res 82: 468-475, 2009.

39. Suzuki H, Eguchi K, Ohtsu H, Higuchi S, Dhobale S, Frank GD, Motley ED, and Eguchi S. Activation of endothelial nitric oxide synthase by the angiotensin II type 1 receptor. Endocrinology 147: 5914-5920, 2006.

40. Takaishi $\mathrm{H}$, Taniguchi $\mathrm{T}$, Takahashi A, Ishikawa $\mathrm{Y}$, and Yokoyama M. High glucose accelerates MCP-1 production via p38 MAPK in vascular endothelial cells. Biochem Biophys Res Commun 305: 122-128, 2003.

41. Thomas SR, Chen K, and Keaney JF, Jr. Oxidative stress and endothelial nitric oxide bioactivity. Antioxid Redox Signal 5: 181-194, 2003.

42. Thomas SR, Witting PK, and Drummond GR. Redox control of endothelial function and dysfunction: Mmolecular mechanisms and therapeutic opportunities. Antioxid Redox Signal 10: 1713-1765, 2008.

43. Touyz RM and Schiffrin EL. Signal transduction mechanisms mediating the physiological and pathophysiological actions of angiotensin II in vascular smooth muscle cells. Pharmacol Rev 52: 639-672, 2000.

44. Tropeano AI, Boutouyrie P, Pannier B, Joannides R, Balkestein E, Katsahian S, Laloux B, Thuillez C, StruijkerBoudier $\mathrm{H}$, and Laurent $\mathrm{S}$. Brachial pressure-independent reduction in carotid stiffness after long-term angiotensinconverting enzyme inhibition in diabetic hypertensives. Hypertension 48: 80-86, 2006.

45. Wenzel P, Schulz E, Oelze M, Muller J, Schuhmacher S, Alhamdani MS, Debrezion J, Hortmann M, Reifenberg K, Fleming I, Munzel T, and Daiber A. AT1-receptor blockade by telmisartan upregulates GTP-cyclohydrolase I and protects eNOS in diabetic rats. Free Radic Biol Med 45: 619-626, 2008.

46. Xu ZG, Lanting L, Vaziri ND, Li Z, Sepassi L, RodriguezIturbe $B$, and Natarajan R. Upregulation of angiotensin II type 1 receptor, inflammatory mediators, and enzymes of arachidonate metabolism in obese Zucker rat kidney: Reversal by angiotensin II type 1 receptor blockade. Circulation 111: 1962-1969, 2005.

47. Yusuf S, Sleight P, Pogue J, Bosch J, Davies R, and Dagenais G. Effects of an angiotensin-converting-enzyme inhibitor, ramipril, on cardiovascular events in high-risk patients. The Heart Outcomes Prevention Evaluation Study Investigators. N Engl J Med 342: 145-153, 2000.
48. Zhao X, Li X, Trusa S, and Olson SC. Angiotensin type 1 receptor is linked to inhibition of nitric oxide production in pulmonary endothelial cells. Regul Pept 132: 113-122, 2005.

49. Zheng F, Zeng YJ, Plati AR, Elliot SJ, Berho M, Potier M, Striker LJ, and Striker GE. Combined AGE inhibition and ACEi decreases the progression of established diabetic nephropathy in B6 db/db mice. Kidney Int 70: 507-514, 2006.

50. Zhong JC, Yu XY, Huang Y, Yung LM, Lau CW, and Lin SG. Apelin modulates aortic vascular tone via endothelial nitric oxide synthase phosphorylation pathway in diabetic mice. Cardiovasc Res 74: 388-395, 2007.

Address correspondence to: Yu Huang, Ph.D.

Institute of Vascular Medicine

School of Biomedical Sciences Chinese University of Hong Kong Hong Kong

China

E-mail: yu-huang@cuhk.edu.hk

Date of first submission to ARS Central, August 21, 2009; date of final revised submission, January 25, 2010; date of acceptance, February 6, 2010.

$\begin{aligned} & \text { Abbreviations Used } \\ & \mathrm{ACE}=\text { angiotensin converting enzyme } \\ & \mathrm{ACh}=\text { acetylcholine } \\ & \mathrm{Ang} \mathrm{II}=\text { angiotensin II } \\ & \mathrm{ARB}=\text { angiotensin receptor blocker } \\ & \mathrm{AT}_{1} \mathrm{R}=\text { angiotensin II type } 1 \text { receptor } \\ & \mathrm{AT}_{2} \mathrm{R}=\text { angiotensin } \mathrm{II} \text { type } 2 \text { receptor } \\ & \mathrm{DHE}=\text { dihydroethidium } \\ & \mathrm{eNOS}=\text { endothelial nitric oxide synthase } \\ & \mathrm{L}-\mathrm{NAME}=\mathrm{N}^{G} \text {-nitro-L-arginine methyl ester } \\ & \mathrm{NO}=\text { nitric oxide } \\ & \mathrm{PBS}=\text { phosphate buffer solution } \\ & \mathrm{RAAS}=\text { renin angiotensin aldosterone system } \\ & \mathrm{ROS}=\text { reactive oxygen species } \\ & \mathrm{SNP}=\text { sodium nitroprusside } \\ & \mathrm{SOD}=\text { superoxide dismutase }\end{aligned}$

